Türkiye Jeoloji Bülteni
Geological Bulletin of Turkey
$60(2017) 243-258$
http://tjb.jmo.org.tr

\title{
Güre (Balıkesir) Jeotermal Alanının Jeolojisi, Hidrojeokimyası ve Aktif Tektonikle İlişkisi
} Geology and Hydrogeochemistry of Güre (Ballkesir) Geothermal Field and its Relationship with Active Tectonic

\author{
Belgin Kaçar ${ }^{1 *}$, Süha Özden², Özkan Ateş ${ }^{3}$ \\ ${ }^{1}$ Mithatpaşa Mah. 212 Sok. Palmiye Apt. No: 2 Daire 1 Konak/İzmir \\ ${ }^{2}$ Çanakkale Onsekiz Mart Üniversitesi, Mühendislik Fakültesi, \\ Jeoloji Mühendisliği Bölümü, Çanakkale \\ ${ }^{3}$ Çanakkale Onsekiz Mart Üniversitesi, Çan Meslek Yüksekokulu, Madencilik ve \\ Maden Çıkarma Bölümü, Çan/Çanakkale
}

Geliş/Received : 10.02.2017 • Düzeltilmiş Metin Geliş/Revised Manuscript Received : 22.03.2017 • Kabul/Accepted : 24.03.2017 • Bask1/Printed : 01.04 .2017 Araştırma Makalesi/Research Article Türkiye Jeol. Bül./Geol. Bull. Turkey

Öz: Güre jeotermal alanı KB Anadolu'da Balıkesir ili sınırları içerisinde yer alır. Bu çalışmada alanın ve yakın çevresinin jeolojik ve hidrojeokimyasal özellikleri ile aktif tektonizmayla ilişkisi ortaya çıkarılmaya çalışılmıştır. Güre jeotermal alanının temelini Paleozoyik yaşlı Kazdağ Grubu'na ait kayaçlar oluşturmaktadır. Temel kayaların üzerinde uyumsuzlukla Triyas yaşlı Karakaya formasyonu yer almaktadır. Kretase yaşlı Çetmi melanjı bu temelin üzerinde tektonik olarak durmaktadır. Üst Oligosen-Alt Miyosen yaşlı Hallaçlar volkaniti ve Oligo-Miyosen yaşlı granodiyoritler, tüm yaşlı birimleri keserek yerleşmişlerdir. Kuvaterner yaşlı alüvyon çalışma alanındaki tüm birimleri uyumsuz olarak üzerlemektedir. Türkiye Diri Fay Haritalarında da aktif fay olarak gösterilen Edremit Fay Zonu'nun doğu kısmı üzerinde yer alan Güre jeotermal alanı yaklaşık DKD-BGB doğrultulu ve güneye eğimli bir normal fay tarafindan kontrol edilmektedir. Aletsel dönemde Eylül 2013 ile Ağustos 2014 tarihleri arasında bu bölge ve yakın civarında $\mathrm{M}=3.0$ dan büyük yaklaşık 12 adet deprem meydana gelmiştir. Güre jeotermal alanında yer alan dört adet sıcak su sondajından gelen jeotermal sulardan 21.09.2013-16.08.2014 tarihleri arasında 12 farkl dönemde bir izleme çalışması yapılmıştır. Yapılan sıcak su fiziko-kimyası ölçümü çalışmaları sırasında ve eş zamanlı olarak bölgede ve yakın civarında meydana depremler öncesi ve sonrasında; termal sularda özellikle $\mathrm{T}^{0} \mathrm{C}, \mathrm{pH}$ ve $\mathrm{EC}$ değerlerinde bir değişim olduğu gözlenmiştir. Bununla birlikte, termal suyun kimyasal analizleri sonucunda özellikle başta $\mathrm{Cl}^{-}, \mathrm{Na}^{+}$ve $\mathrm{SO}_{4}^{-2}$ olmak üzere birçok elementel düzeyde artış ya da azalmanın olduğu tespit edilmiştir. $\mathrm{Bu}$ değişimlerin bölgedeki aktif tektonik rejim ile doğrudan ilişkili olduğu sonucuna varılmıştır.

Anahtar Kelimeler: Aktif Fay, Deprem, Güre, Hidrojeokimya, Jeotermal

\begin{abstract}
Güre geothermal field is located in NW Anatolia within the boundaries of Ballkesir. This study attempts to determine the geologic and hydrogeochemical characteristics of the field and close surroundings and their correlation with active tectonism. The basement of Güre geothermal field is rocks of the Paleozoic-age Kazdağ Group. Above the basement, the Triassic-age Karakaya Formation lies above an unconformity. The Cretaceous Çetmi melange tectonically overlies this basement. The Upper Oligocene-Lower Miocene Hallaçlar volcanics and Oligo-Miocene granodiorites were emplaced by cutting all older units. Quaternary alluvium unconformably overlies all units in the study area. The Güre geothermal field located on the east section of the Edremit Fault Zone, marked as an active fault on the Active Fault Map of Turkey, is controlled by a nearly ENE-WSW oriented, south-dipping normal fault. In the instrumental period from September 2013 to August 2014, nearly 12 earthquakes occurred in this region and close surroundings with $M=3.0$ or more. Geothermal water from four hot-water wells in the Güre goethermal field had monitoring studies performed in 12 different periods from 21.09.2013-16.08.2014. Physicochemical measurements and experimental studies of water from Güre geothermal field were compared simultaneous to earthquakes in the region. Before and after earthquakes changes were observed in these thermal waters, especially
\end{abstract}


$T^{\circ} \mathrm{C}, \mathrm{pH}$ and EC values. Additionally chemical analysis of the water identified increases or reductions in many elemental levels, especially $\mathrm{Cl}, \mathrm{Na}^{+}$and $\mathrm{SO}_{4}^{-2}$. It was concluded that these variations were directly related to the active tectonic regime in the region.

Key Words: Active Fault, Earthquake, Geothermal, Güre, Hydrogeochemisty

\section{GíRiş}

Yeraltı suyu bileşimlerindeki fiziksel ve kimyasal değişimlerin deprem öncesinde oluşan ilk sarsıntılarla başladığı ve enerji boşalımı maksimum değerlere ulaştığı, sonra zamanla normal değerlerine döndüğü bilinmektedir (Şimşek ve Yıldırım, 2000). Depremlerin öncesinde, sirasinda ve sonrasinda yeni su kaynakları oluşumu yada var olan su kaynaklarının kaybolması da olağandır. 1999 İzmit ve Düzce depremlerinde, 2011 Simav depreminde de bazı jeotermal kaynak ve sondaj kuyu sularında fiziksel ve kimyasal değişimler meydana gelmiştir (Şimşek ve Yıldırım, 2000; Ateş, 2014; Ateş ve Tutkun, 2014). Bu çalışmada Balıkesir ili Edremit körfezi kuzeyi boyunca uzanan Edremit Fay Zonu üzerinde yer alan Güre Jeotermal Alanı'nda dört adet sicak su sondajı belirlenmiştir. $\mathrm{Bu}$ sicak su sondajlarından gelen sicak sular Güre Jeotermal Isı Merkezi'nde toplanmaktadır. Sıcak su sondaj noktalarından örnek alınamadığı için 1S1 merkezinde toplanan sıcak su başında yerinde ölçümler ( $\mathrm{pH}$, iletkenlik-EC ve sicaklık- $\left.{ }^{0} \mathrm{C}\right)$ ve alınan sicak su örneklerinden hidrojeokimyasal analizler $\left(\mathrm{Ca}^{+2}, \mathrm{Mg}^{+2}, \mathrm{Na}^{+}, \mathrm{K}^{+}, \mathrm{Cl}^{-}, \mathrm{SO}_{4}{ }^{=}\right.$ve $\mathrm{HCO}_{3}^{-}$ ) yapılarak termal suların hidrojeokimyasal özellikleri ortaya çıkarılmıştır. Örnekleme ve yerinde ölçümler düzenli olarak belirli peryotlarla yapılmıştır. Bu çalışmada sismik olarak oldukça aktif olan Güre ve civarında yer alan sicak su kaynaklarının hidrojeokimyasal özellikleri ve bölgenin aktif tektonik yapısı ile olan ilişkisinin ortaya çıkarılması amaçlanmıştır.

\section{MATERYAL ve YÖNTEM}

Bu çalışmada Balıkesir ili, Edremit ilçesi batısında yer alan Güre Jeotermal Alanı'nda aktif faylarla ilişkili sıcak su kaynakları belirlenmiştir. Bununla beraber jeotermal alanın ve yakın civarının jeoloji ve aktif fay haritaları yenilenmiştir. Ayrıca arazide yer alan sıcak su sondajlarından 1sı merkezine gelen sıcak suda bir yıl içerisinde 12 örnekleme döneminde yerinde ölçüm ve su örneklemesi gerçekleşmiştir. Sıcak su başında $\mathrm{pH}$, iletkenlik (EC) ve sıcaklık $\left(\mathrm{T}^{0} \mathrm{C}\right)$ ölçümleri yapılmıştır. Sicak suyun $\mathrm{HCO}_{3}^{-}$analizleri laboratuvarda titrasyon yöntemi ile yapılmıştır. Alınan sıcak su örneklerini kimyasal analizlerinden major anyon ve katyon $\left(\mathrm{Ca}^{+2}, \mathrm{Mg}^{+2}, \mathrm{Na}^{+}, \mathrm{K}^{+}, \mathrm{Cl}^{-}, \mathrm{SO}_{4}=\right)$ analizleri ise ACME LABS-Acme Analitik Laboratuvar Hizmetleri Ltd. Şti. laboratuvarlarında yapılmıştır.

\section{ÇALIŞMA SAHASININ JEOLOJISİ, AKTİF TEKTONİĞİ ve DEPREMSELLİĞİ}

Çalışma alanın KB Anadolu'da Balıkesir ili, Edremit ilçesi, Güre beldesinde yer almaktadır (Şekil 1).

Çalışma alanı ve yakın civarı jeolojik olarak Kazdağlarının güney kısmını temsil eder. $\mathrm{Bu}$ kesim günümüzde Edremit Fay Zonu ile sınırlıdır. Çalışma sahasının temelinde Paleozoyik yaşlı Kazdă̆ Grubu'na ait Alakeçili milonit zonu, Sütüven Formasyonu ve Mermer üyesi oluşturmaktadır (Bingöl, 1975; Okay, 1987; Okay vd. 1990; Duru vd. 2004; Yüzer ve Yunay, 2012). Temel kayaların üzerinde uyumsuzlukla Triyas yaşlı Karakaya formasyonu yer almaktadır (Bingöl, 1968; Bingöl vd. 1973). Kretase yaşlı Çetmi melanjı bu temelin üzerinde tektonik olarak durmaktadır (Okay vd. 1990). Üst Oligosen-Alt Miyosen yaşlı Hallaçlar volkaniti (Ercan vd. 1995) ve Oligo-Miyosen yaşlı granodiyoritler (Duru vd. 2004) tüm yaşlı birimleri keserek yerleşmişlerdir. Tüm bu birimler üzerinde de uyumsuz olarak Kuvaterner yaşlı alüvyon ve kıyı çökelleri yer almaktadır (Şekil 2). 


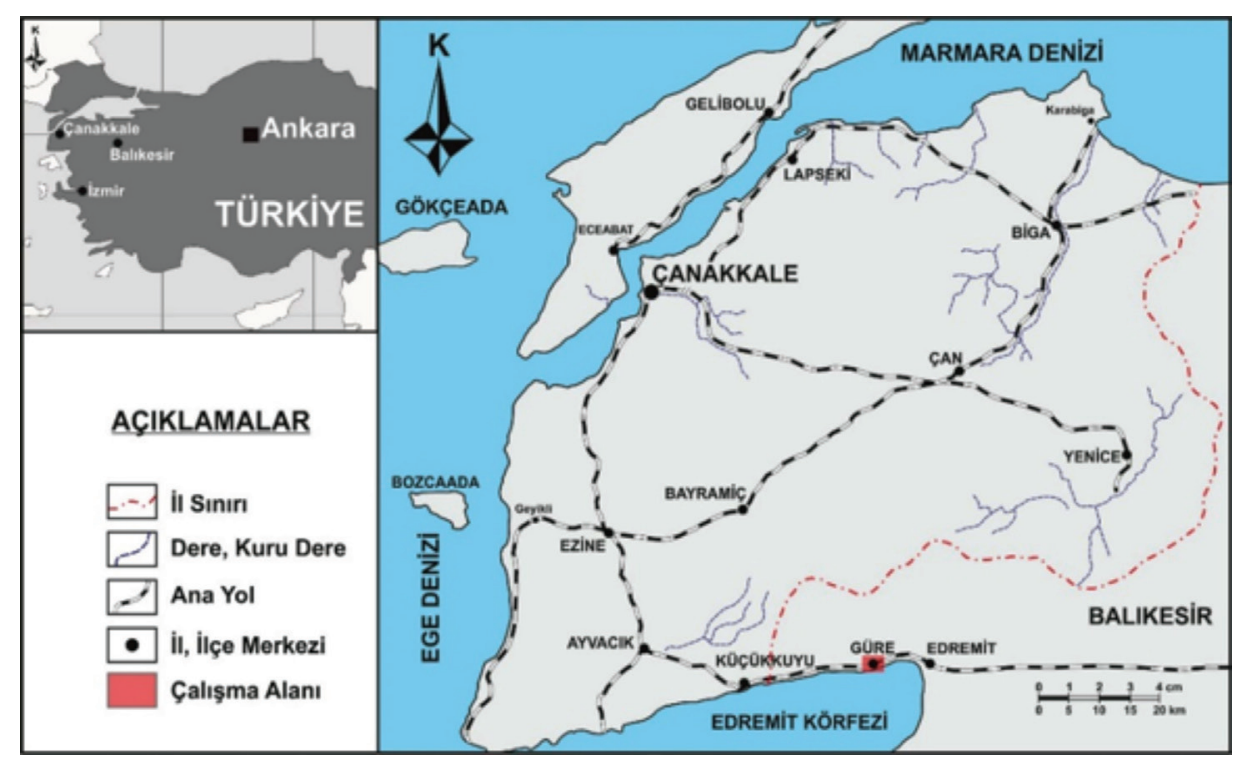

Şekil 1. Çalışma alanının yer bulduru haritası

Figure 1. Location map of the study area

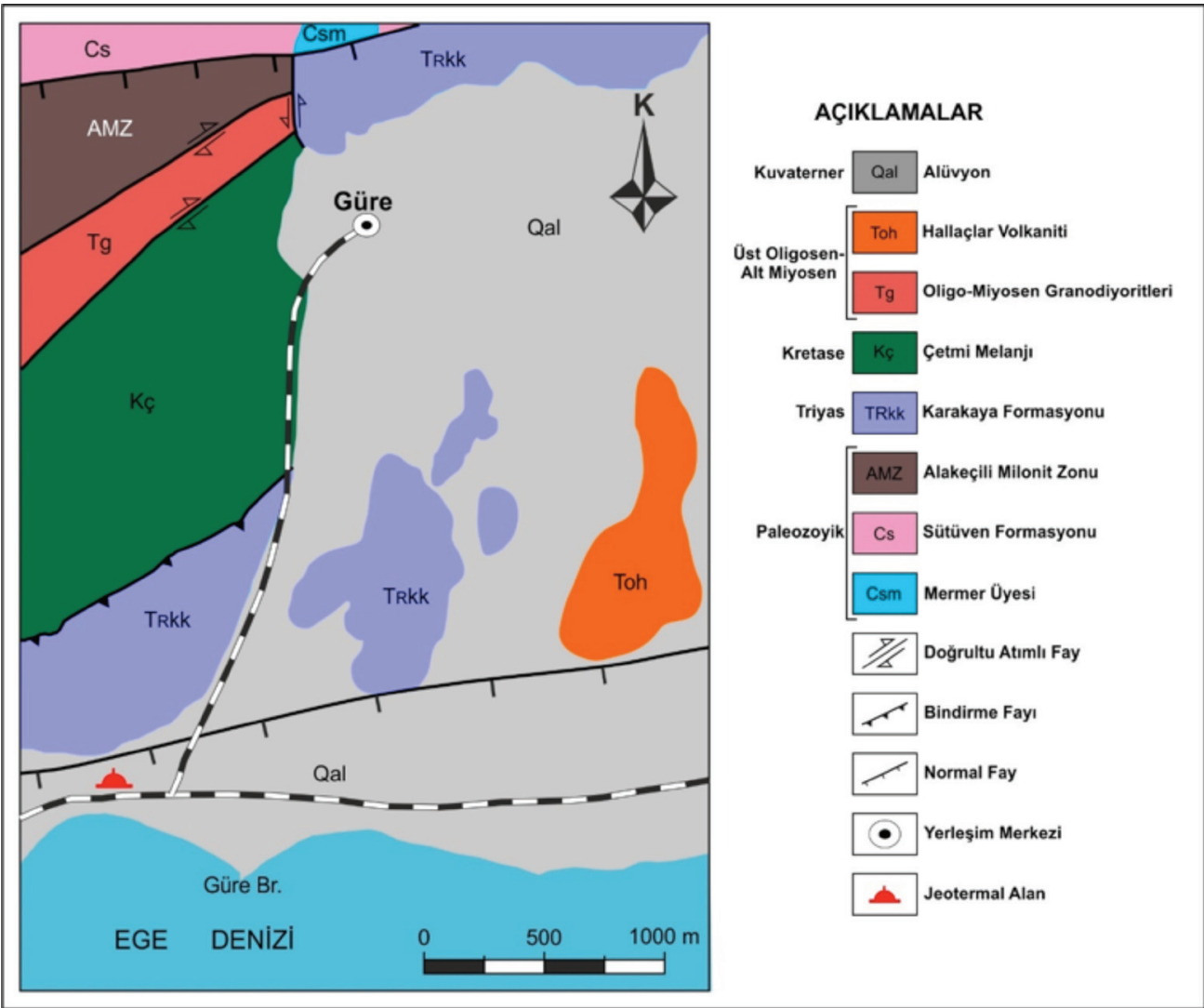

Şekil 2. Çalışma alanının jeoloji haritası

Figure 2. Geological map of the study area 
Çalışma alanının güneyi boyunca uzanan ve üzerinde sıcak su kaynaklarının da yer aldığ1 Güre-Ilıca fayı yaklaşık DKD-BGB doğrultusundadır ve eğim atımlı normal fay karakterindedir (Şekil 3). Bir diğer eğim atımlı normal fay olan Kavlaklar-Yassıçalı fayı çalışma alanının KB sinda metamorfik birimler arasında yaklaşık DKD-BGB doğrultusunda uzanır (Şekil 4). Ayrıca çalışma alanında metamorfik birimler sınırında KD-GB doğrultulu bir bindirme fayı yer almaktadır. Çalışma alanının KB sında doğrultusu KD-GB olan sağ yanal doğrultu atımlı faylar ve doğrultusu yaklaşık K-G olan sol yönlü doğrultu bir fay gözlenmiştir.

Çalışma alanı Edremit Körfezi ile Kazdağı arasında kalmaktadır. Edremit Körfezi, kuzeybatı Ege'de Kuzey Anadolu Fayı'nın orta ve güney kolları arasında yer alan, kuzey sahili KDD-GBB doğrultulu normal fayların denetiminde tektonik olarak aktif bir genç havzadır (Alpar ve Yaltırak, 2002). Edremit Körfezi'nin çökmesi ve Kazdağ 1 kütlesinin yükselmesinde, KD-GB doğrultulu atımlı fayların Edremit Körfezi bloğunun saatin ters yönünde döndürülmesi ile oluşan yerel bir K-G gerilmenin etkisi bulunmaktadir (Alpar ve Yaltırak, 2002). Kazdağı Edremit Körfezi grabenin kuzeyinde asimetrik olarak yükselen bir horsta karşılık gelmektedir. Edremit Körfezi Kuzey sahili de bu sistemin oluşturduğu kademeli faylarla yükselmekte körfez orta kesimi de aynı şekilde çökmektedir. Çalışma alanında bulunan Güre-Ilıca ve Kavlaklar-Yassıçalı fayı Kazdağı yükselimini Edremit Körfezi'nin çöküşünü sağlayan basamak şekilli normal faylar oluşturmaktadır (Alpar ve Yaltırak, 2002).

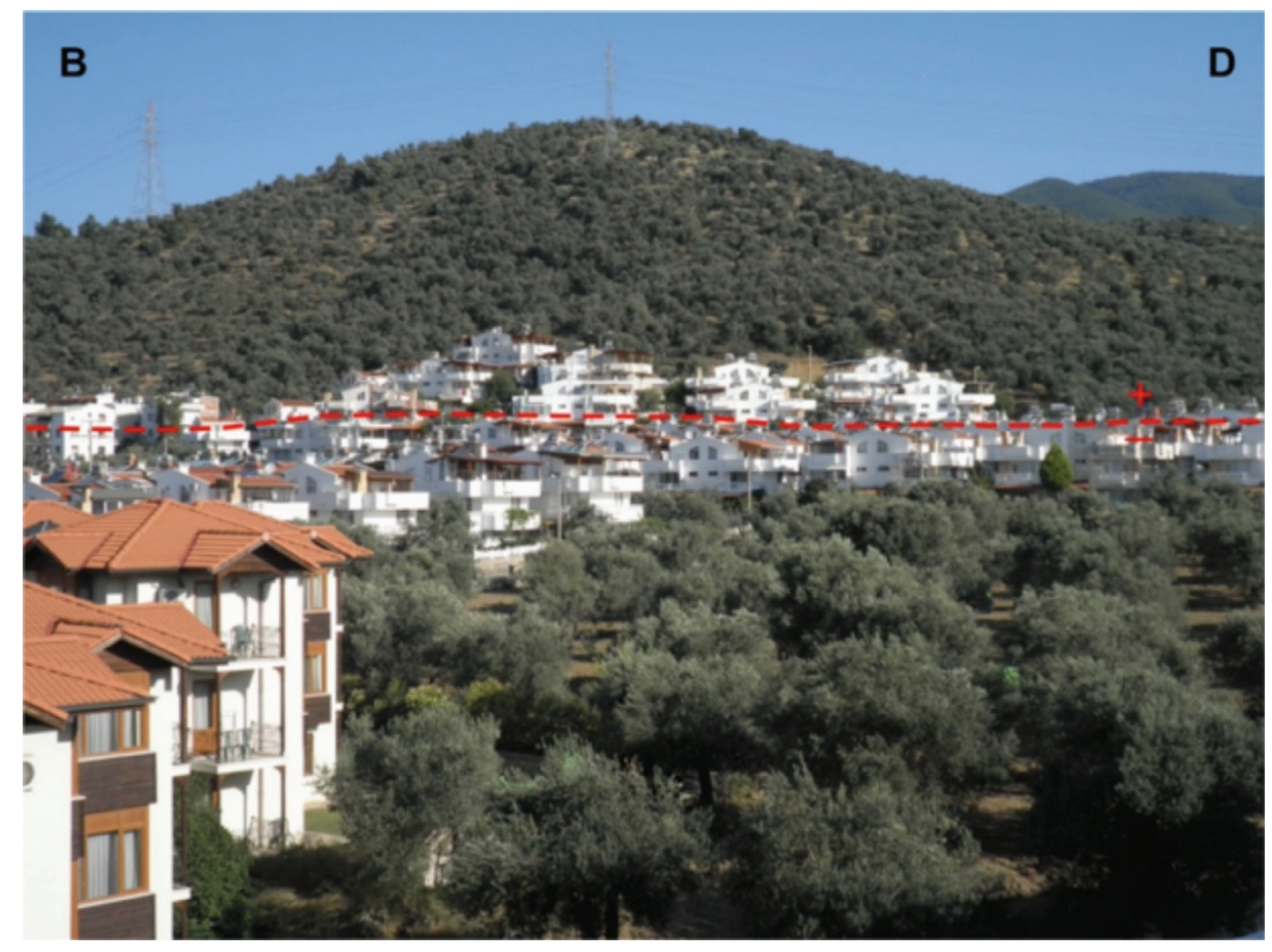

Şekil 3. Güre-Ilıca normal fayının morfolojik görünümü

Figure 3. Morphological view of Güre-Ilıca normal fault 


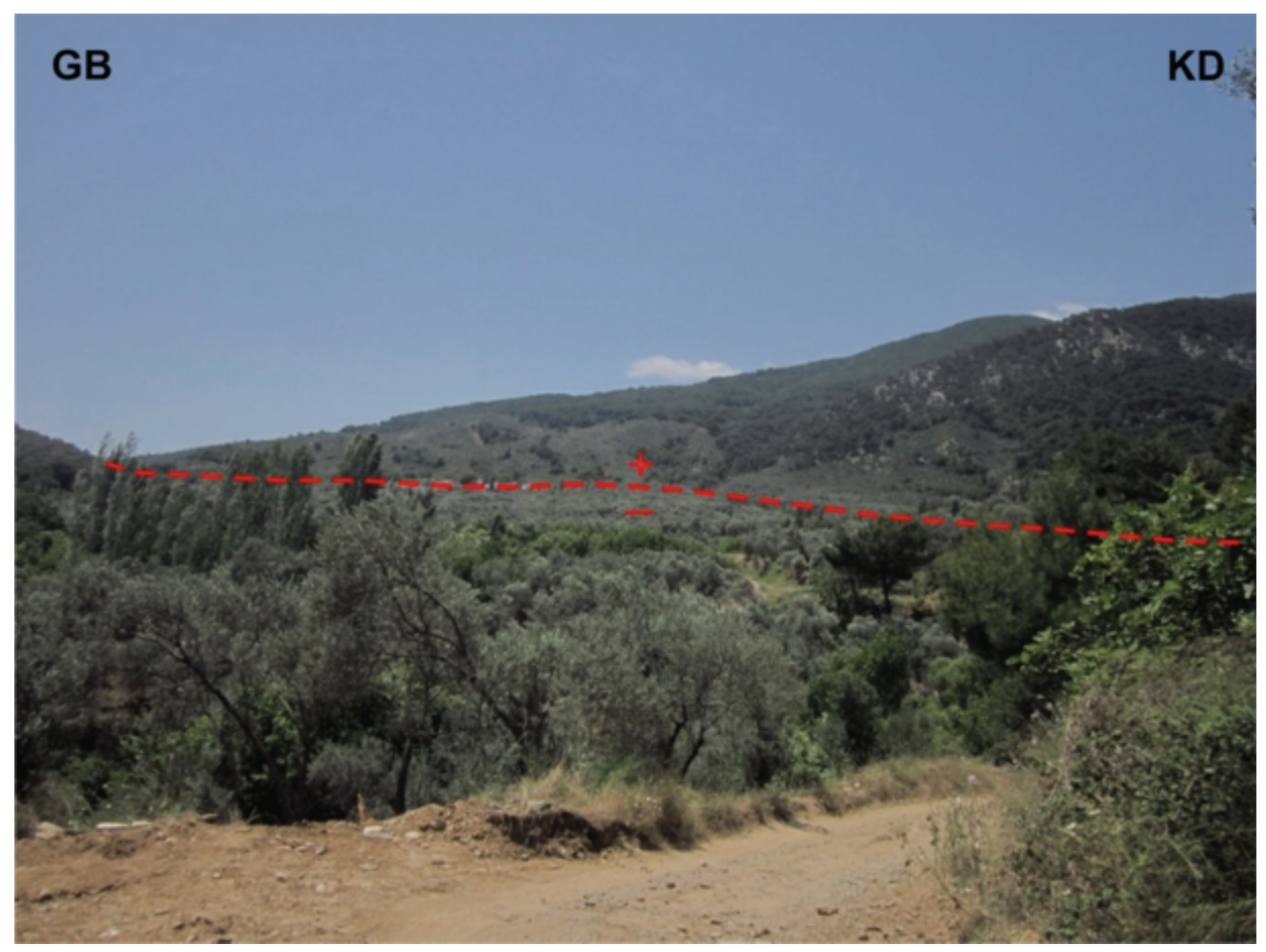

Şekil 4.Kavlaklar-Yassıçalı normal fayının morfolojik görünümü

Figure 4. Morphological view of Kavlaklar-Yassıçalı normal fault

Bat1 Anadolu'daki jeotermal aktiviteler çoğunlukla graben sistemleri içerisinde yer almışlardır. Büyük Menderes, Gediz, Simav, Bakırçay, İzmir, Gönen ve Edremit çevresinde 123 sıcak su kaynağı ve 36 jeotermal saha tanımlanmıştır (Akkuş vd. 2005; Şimşek, 2003). Depremsellikle ilişkili olduğu saptanan bölgesel faylar özellikle kaplıcalarla paralellik göstermektedir.

Çalışma alanı ve yakın çevresinde hasar yapıc1 en büyük deprem büyüklüğü $\mathrm{Ms}=7.0$ olan
6 Ekim 1944 Ayvalık-Edremit depremidir. Bu deprem Edremit Körfezi'nin kıyıları üzerinde yer alan köylerde, Ayvacık'ta ve Midilli Adası'nda ağır hasara neden olmuştur.

Ayrıca, 2013-2014 yıllarında arasında, çalışma alanı ve civarında meydana gelmiş çeşitli büyüklüklerdeki 126 adet deprem ve 24.05.2014 tarihinde büyüklüğü $\mathrm{M}=6.5$ olan Gökçeada açıkları-Ege Denizi depremi kaydedilmiştir (Şekil $5,6)$. 


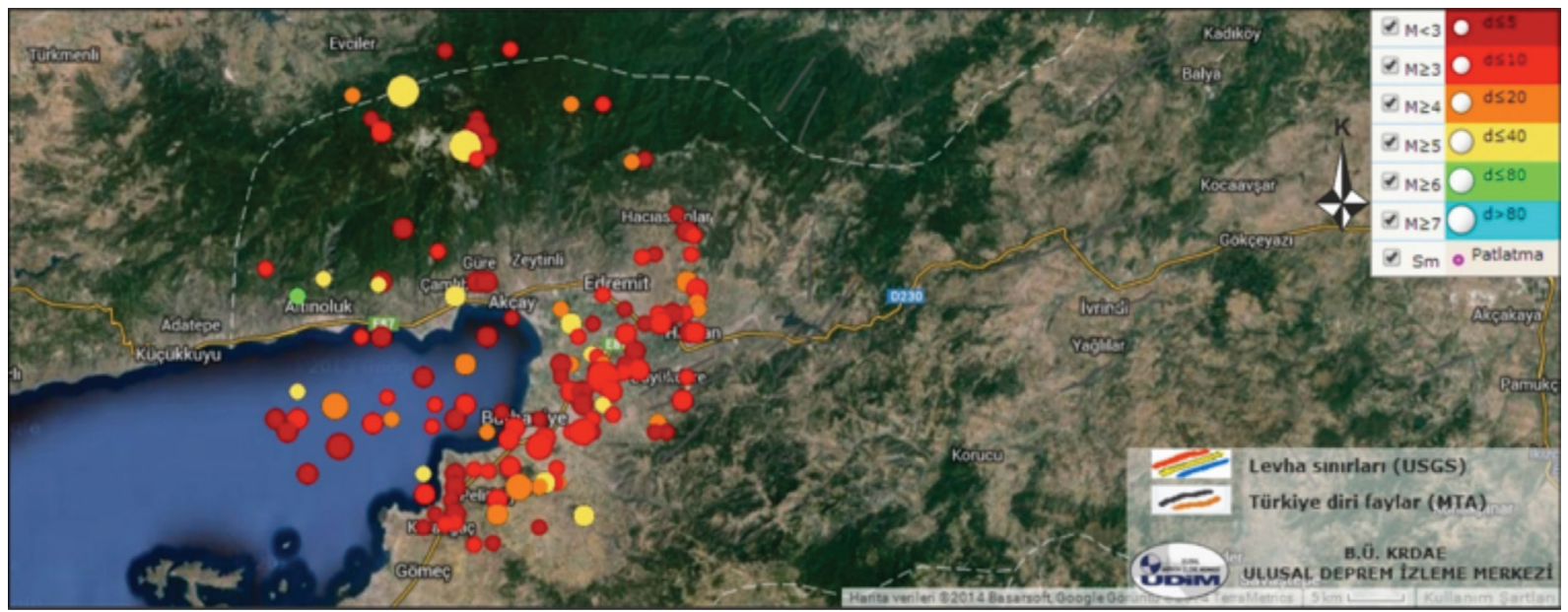

Şekil 5. Güre ve civarında aletsel dönemde meydana gelmiş büyüklüğü $\mathrm{M}>2.0$ depremler (udim.koeri.boun.edu.tr) Figure 5. Earthquakes which has $M>2.0$ magnitude in the instrumental period at Güre and surrounding (udim.koeri. boun.edu.tr)

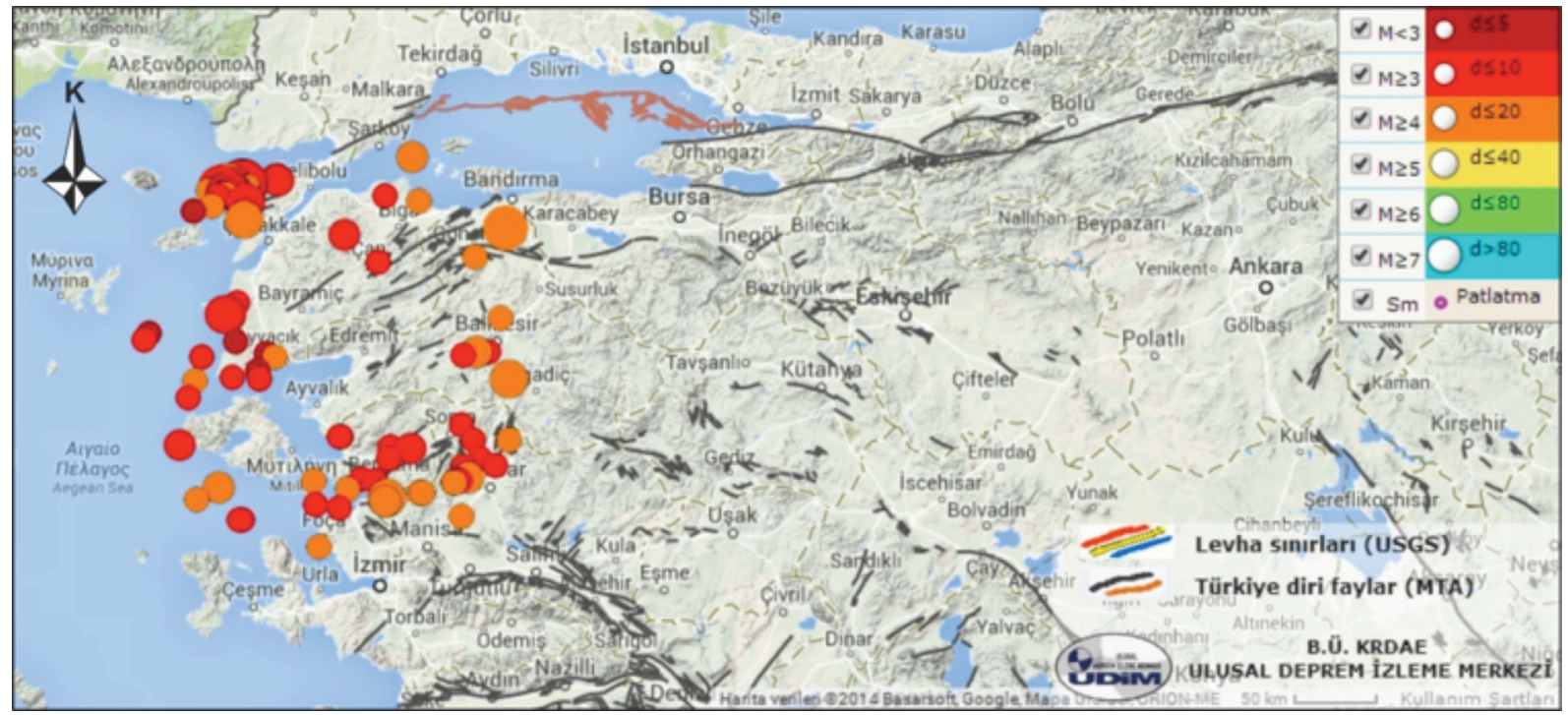

Şekil 6. Güre ve civarında 21.09.2013 ve 16.08.2014 tarihleri arasında meydana gelmiş büyüklüğü $\mathrm{M}>3.0$ olan depremler (udim.koeri.boun.edu.tr)

Figure 6. Earthquakes which has M>3.0 magnitude between 21.09.2013 and 16.08.2014 at Güre and surrounding (udim.koeri.boun.edu.tr) 


\section{ÇALIŞMA ALANINDAKİ JEOTERMAL SULARIN HIDROJEOKIMMYASAL ÖZELLIKKLERİ}

Bu çalışmada Eylül 2013-Ağustos 2014 tarihleri arasında 12 farklı dönemde Balıkesir ili, Edremit ilçesi, Güre beldesinde yer alan jeotermal alanda belirlenen sicak su sondaj kuyularından periyodik olarak yerinde ölçüm ve su örnekleme çalışmaları yapılmıştır. Çalışma sahasında arazide ölçülebilecek ve örnek alınabilecek sıcak su çıkışı bulunmadığından Güre jeotermal 1sı merkezinden ölçüm ve örnekleme yapılmıştır. Örnek alınan Güre jeotermal 1s1 merkezine bağlı dört adet sicak su sondaj1 bulunmaktadır. Bu sicak su sondajları İGJ-1, İGJ-2, İGJ-3 ve İGJ-4 olarak adlandırılmıştır (Çizelge 1) (Şekil 7).

Çizelge 1. Güre jeotermal alanında yer alan sıcak su sondajları

Table 1. Geothermal water drillings in Güre geothermal area

\begin{tabular}{cccc}
\hline Kuyu No & Koordinat & Derinlik (m) & Kuyu Başı Sıcaklık \\
\hline İGJ-1 & $490224 \mathrm{D} / 4832366 \mathrm{~K}$ & 167 & $64^{\circ} \mathrm{C}$ \\
İGJ-2 & $490060 \mathrm{D} / 4382174 \mathrm{~K}$ & 250 & $56,3^{\circ} \mathrm{C}$ \\
İGJ-3 & $490215 \mathrm{D} / 4382392 \mathrm{~K}$ & 206 & $67^{\circ} \mathrm{C}$ \\
İGJ-4 & $490332 \mathrm{D} / 4382392 \mathrm{~K}$ & 250 & $67^{\circ} \mathrm{C}$ \\
\hline
\end{tabular}

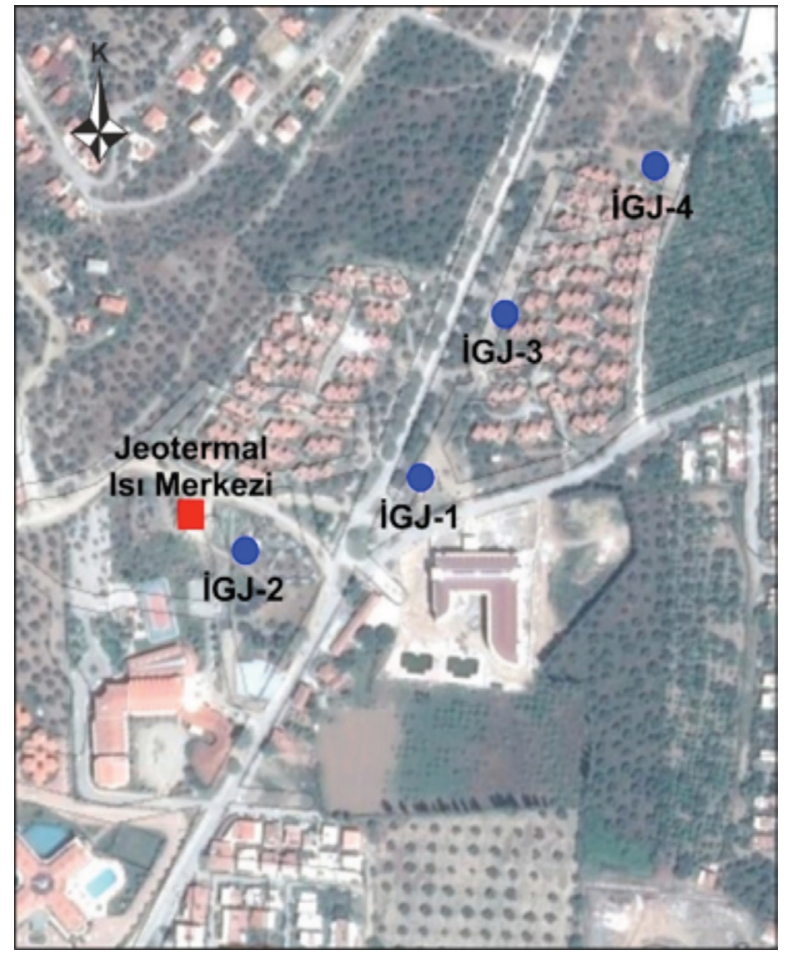

Şekil 7. Güre jeotermal alanındaki sıcak su sondaj kuyu yerlerininin Google Earth görüntüsü

Figure 7. Google Earth image of geothermal water drilling locations in Güre geothermal area
Güre jeotermal alanında 21.09.201316.08.2014 tarihleri arasında 12 farklı dönemde periyodik olarak yerinde ölçüm ve su örnekleme çalışması yapılarak termal suyun fiziksel ve kimyasal özellikleri belirlenmiştir (Çizelge 2).

Major anyon/katyon analiz sonuçları, su tipini belirlemek üzere Piper ve Schoeller hidrojeokimyasal değerlendirme amaçlı sayısal diyagramlarına aktarılmıştır. Alandaki su tipleri incelendiğinde Güre Jeotermal alanındaki su tipi $\mathrm{Na}-\mathrm{SO}_{4} 11$ su tipini yansitmaktadır ve kendi aralarında gösterdikleri benzer özelliklerden dolayı bu üç ayrı sıcak su kaynağı için eş kökenli, aynı hazneye ve beslenme alanına ait sular olarak yorum yapılabilir (Şekil 8, 9). Çalışma alanındaki sıcak su kaynağında katyon dizilimleri $\left(\mathrm{Na}^{+}+\mathrm{K}^{+}\right)>\left(\mathrm{Ca}^{+2}\right)>\left(\mathrm{Mg}^{+2}\right) \quad$ şeklindedir. Anyon dizilimleri ise $\left(\mathrm{SO}_{4}^{-2}\right)>\left(\mathrm{HCO}_{3}^{-}\right)>\left(\mathrm{Cl}^{-}\right)$şeklindedir. 
Çizelge 2. Çalışma alanındaki sıcak suyun majör iyon derişimleri

Table 2. Major ion concentrations of thermal water in the study area

\begin{tabular}{cccccccccccc}
\hline Lokasyon & Tarih & $\begin{array}{c}\mathbf{T} \\
\left({ }^{\mathbf{}} \mathbf{C}\right)\end{array}$ & $\mathbf{p H}$ & $\begin{array}{c}\mathbf{E C} \\
(\boldsymbol{\mu \mathbf { s }} / \mathbf{c m})\end{array}$ & $\begin{array}{c}\mathbf{N a}^{+} \\
(\mathbf{m g} / \mathbf{l})\end{array}$ & $\begin{array}{c}\mathbf{C a}^{+2} \\
(\mathbf{m g} / \mathbf{l})\end{array}$ & $\begin{array}{c}\mathbf{K}^{+} \\
(\mathbf{m g} / \mathbf{l})\end{array}$ & $\begin{array}{c}\mathbf{M g}^{+2} \\
(\mathbf{m g} / \mathbf{l})\end{array}$ & $\begin{array}{c}\mathbf{C l}^{-} \\
(\mathbf{m g} / \mathbf{l})\end{array}$ & $\begin{array}{c}\mathbf{S O}_{4}^{-2} \\
(\mathbf{m g} / \mathbf{l})\end{array}$ & $\begin{array}{c}\mathbf{H C O}_{\mathbf{3}}^{-} \\
(\mathbf{m g} / \mathbf{l})\end{array}$ \\
\hline İGJ-1 & 21.09 .2013 & 56.2 & 8.52 & 1113 & 218.97 & 14.95 & 5.01 & 0.06 & 51.00 & 310.00 & 40.57 \\
İGJ-1 & 02.11 .2013 & 56.3 & 8.53 & 1043 & 201.01 & 13.00 & 4.63 & 0.06 & 48.00 & 290.00 & 64.02 \\
İGJ-4 & 30.11 .2013 & 62.8 & 8.35 & 1356 & 256.74 & 22.14 & 7.22 & 0.09 & 47.00 & 390.00 & 90.36 \\
İGJ-4 & 05.01 .2014 & 59.7 & 8.29 & 1343 & 254.16 & 22.76 & 7.00 & 0.10 & 54.00 & 360.00 & 41.18 \\
İGJ1-İGJ4 & 01.02 .2014 & 58.4 & 8.48 & 1208 & 241.34 & 22.79 & 6.79 & 0.12 & 52.00 & 370.00 & 35.99 \\
İGJ1-İGJ4 & 08.03 .2014 & 58.5 & 8.48 & 1210 & 241.71 & 21.83 & 6.57 & 0.10 & 51.00 & 360.00 & 37.52 \\
İGJ-2 & 05.04 .2014 & 46.2 & 8.2 & 862.1 & 182.10 & 11.35 & 3.79 & 0.12 & 43.00 & 330.00 & 47.89 \\
İGJ-4 & 09.04 .2014 & 46.7 & 8.65 & 851 & 245.90 & 22.62 & 7.00 & 0.16 & 51.00 & 300.00 & 30.81 \\
İGJ-2 & 26.04 .2014 & 45.7 & 8.63 & 864.7 & 166.32 & 9.27 & 3.73 & 0.10 & 42.00 & 360.00 & 60.09 \\
İGJ-2 & 24.05 .2014 & 46.2 & 8.63 & 865.7 & 173.05 & 9.10 & 3.80 & 0.10 & 39.00 & 270.00 & 38.74 \\
İGJ-2 & 24.05 .2014 & 46.8 & 8.44 & 900.7 & 167.92 & 9.03 & 3.75 & 0.11 & 39.00 & 250.00 & 57.95 \\
İGJ-2 & 28.06 .2014 & 55.8 & 8.54 & 1063 & 167.33 & 9.19 & 3.87 & 0.24 & 44.00 & 290.00 & 45.75 \\
İGJ-1 & 16.08 .2014 & 56.2 & 8.52 & 1113 & 198,78 & 13,22 & 4,55 & 0,10 & 38,00 & 320.00 & 36.6 \\
\hline
\end{tabular}

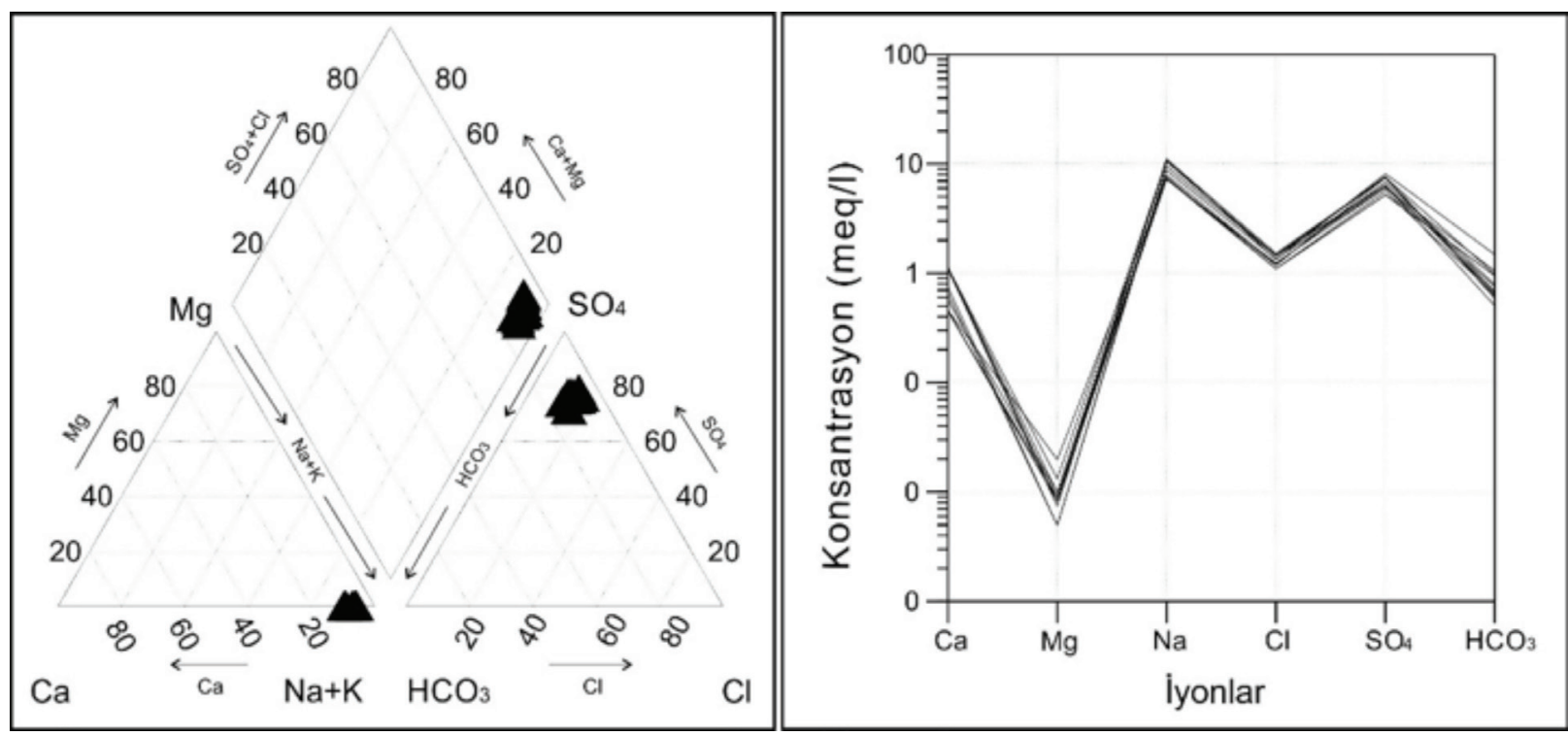

Şekil 8. Çalışma sahasındaki sıcak sulardan alınan verilere göre hazırlanmış Piper ve Schoeller diyagramları Figure 8. Piper and Schoeller diagrams of Güre thermal water 
Çalışma alanındaki sıcak su kaynaklarının hidrojeokimyasal özellikleri bölgede meydana gelen depremler ile ilişkilendirildiğinde çalışma dönemi boyunca suların fiziksel ve kimyasal özelliklerini etkileyen 12 deprem kaydı elde edilmiştir (Çizelge 3).

Çizelge 3. Güre jeotermal sistemini etkileyen depremler

Table 3. Earthquakes which effects Güre geothermal system

\begin{tabular}{|c|c|c|c|c|c|c|c|}
\hline No & $\begin{array}{l}\text { Tarih } \\
\text { Saat }\end{array}$ & Enlem (K) & Boylam (D) & $\begin{array}{c}\text { Derinlik } \\
(\mathbf{k m})\end{array}$ & $\begin{array}{l}\text { Büyüklük } \\
\text { (Ms) }\end{array}$ & $\begin{array}{l}\text { Episantr } \\
\text { Uzaklık }\end{array}$ & Kaynak \\
\hline 1 & $\begin{array}{l}02.12 .2013 \\
06: 11: 25\end{array}$ & 39.5750 & 25.9735 & 5.3 & 3.4 & $\begin{array}{c}\text { Gülpınar Açılkları- } \\
\text { Çanakkale } \\
(90 \mathrm{~km})\end{array}$ & $\begin{array}{c}\text { Kandilli } \\
\text { Rasathanesi }\end{array}$ \\
\hline 2 & $\begin{array}{l}08.04 .2014 \\
23: 08: 36\end{array}$ & 39.5948 & 27.7518 & 12.2 & 3.7 & $\begin{array}{c}\text { Küpeler (Balıkesir) } \\
(75 \mathrm{~km})\end{array}$ & $\begin{array}{c}\text { Kandilli } \\
\text { Rasathanesi }\end{array}$ \\
\hline 3 & $\begin{array}{c}24.04 .2014 \\
18: 16: 03\end{array}$ & 39.4508 & 25.9290 & 10.6 & 3.2 & $\begin{array}{c}\text { Gülpınar Açıları- } \\
\text { Çanakkale } \\
(90 \mathrm{~km})\end{array}$ & $\begin{array}{c}\text { Kandilli } \\
\text { Rasathanesi }\end{array}$ \\
\hline 4 & $\begin{array}{c}24.05 .2014 \\
09: 31: 18\end{array}$ & 40.4270 & 26.2398 & 7.2 & 5.1 & $\begin{array}{l}\text { Saros Körfezi } \\
\text { (Ege Denizi) } \\
\quad(120 \mathrm{~km})\end{array}$ & $\begin{array}{c}\text { Kandilli } \\
\text { Rasathanesi }\end{array}$ \\
\hline 5 & $\begin{array}{c}24.05 .2014 \\
09: 33: 48\end{array}$ & 40.4208 & 26.1673 & 7.6 & 4.0 & $\begin{array}{l}\text { Saros Körfezi } \\
\text { (Ege Denizi) } \\
(120 \mathrm{~km})\end{array}$ & $\begin{array}{c}\text { Kandilli } \\
\text { Rasathanesi }\end{array}$ \\
\hline 6 & $\begin{array}{c}24.05 .2014 \\
09: 34: 16\end{array}$ & 40.3377 & 26.2567 & 5.4 & 4.1 & $\begin{array}{l}\text { Saros Körfezi } \\
\text { (Ege Denizi) } \\
\quad(120 \mathrm{~km})\end{array}$ & $\begin{array}{c}\text { Kandilli } \\
\text { Rasathanesi }\end{array}$ \\
\hline 7 & $\begin{array}{c}24.05 .2014 \\
10: 35: 01\end{array}$ & 40.4278 & 26.1382 & 4.9 & 4.2 & $\begin{array}{l}\text { Saros Körfezi } \\
\text { (Ege Denizi) } \\
\quad(120 \mathrm{~km})\end{array}$ & $\begin{array}{c}\text { Kandilli } \\
\text { Rasathanesi }\end{array}$ \\
\hline 8 & $\begin{array}{c}24.05 .2014 \\
12: 25: 00\end{array}$ & 40.2108 & 25.3073 & 10.2 & 6.5 & $\begin{array}{c}\text { Gökçeada Açılkları } \\
\text { (120 km) }\end{array}$ & $\begin{array}{c}\text { Kandilli } \\
\text { Rasathanesi }\end{array}$ \\
\hline 9 & $\begin{array}{c}25.05 .2014 \\
11: 38: 38\end{array}$ & 40.4208 & 26.1515 & 13.0 & 4.9 & $\begin{array}{l}\text { Saros Körfezi } \\
\text { (Ege Denizi) } \\
\quad(120 \mathrm{~km})\end{array}$ & $\begin{array}{c}\text { Kandilli } \\
\text { Rasathanesi }\end{array}$ \\
\hline 10 & $\begin{array}{c}25.05 .2014 \\
11: 47: 55\end{array}$ & 40.4123 & 26.0925 & 6.8 & 4.5 & $\begin{array}{l}\text { Saros Körfezi } \\
\text { (Ege Denizi) } \\
\quad(120 \mathrm{~km})\end{array}$ & $\begin{array}{c}\text { Kandilli } \\
\text { Rasathanesi }\end{array}$ \\
\hline 11 & $\begin{array}{c}28.05 .2014 \\
03: 59: 51\end{array}$ & 40.4218 & 26.1343 & 13.2 & 4.5 & $\begin{array}{l}\text { Saros Körfezi } \\
\text { (Ege Denizi) } \\
\quad(120 \mathrm{~km})\end{array}$ & $\begin{array}{c}\text { Kandilli } \\
\text { Rasathanesi }\end{array}$ \\
\hline 12 & $\begin{array}{c}23.07 .2014 \\
14: 14: 33\end{array}$ & 39.4588 & 26.3410 & 6.0 & 3.0 & $\begin{array}{l}\text { Edremit Körfezi } \\
\quad(30 \mathrm{~km})\end{array}$ & $\begin{array}{c}\text { Kandilli } \\
\text { Rasathanesi }\end{array}$ \\
\hline
\end{tabular}


Derin jeotermal sularda sülfat $\left(\mathrm{SO}_{4}^{-2}\right)$ miktarı azdır. Yüzeye yakın yerlerde hidrojen sülfürün yükseltgenmesi ile artış gösterir $\left(\mathrm{H}_{2} \mathrm{~S}+2 \mathrm{O}_{2}=2 \mathrm{H}^{+}+\mathrm{SO}_{4}^{-2}\right)$. Klorür $\left(\mathrm{Cl}^{-}\right)$, jeotermal sistemlerin aranması ve yorumlanmasında çok kullanılan bir iyondur. Bir kez çözüldükten sonra başka minerallerin bünyesine kolay girmemesi nedeniyle doğrudan jeotermal suyu karakterize eder (Nicholson, 1993). Yüksek derişim doğrudan, derinden ve yüksek debili bir beslenmeyi gösterir. Düşük klorür derişimi yüzey sularının giriş doğrultularını belirtir (Eroğlu ve Aksoy, 2003).
Güre jeotermal alanında 21.09.201316.08.2014 tarihleri arasında yapilan 12 dönem (yaklaşık 1 ay ara ile) boyunca yapılan sıcak su hidrojeokimyası çalışmaları sırasında eş zamanlı olarak bölgede meydana gelen depremlerin öncesi ve sonrasında; termal suda özellikle sicaklık, $\mathrm{pH}$ ve elektriksel iletkenlik değerlerinde değişimlerin olduğu gözlenmiştir. Bununla birlikte kimyasal analizler sonucunda özellikle başta $\mathrm{Cl}^{-}, \mathrm{Na}^{+}$ve $\mathrm{SO}_{4}^{-2}$ olmak üzere birçok elementsel düzeyde artış ya da azalmanın olduğu tespit edilmiştir (Şekil 9, $10,11,12,13,14,15,16,17,18)$.

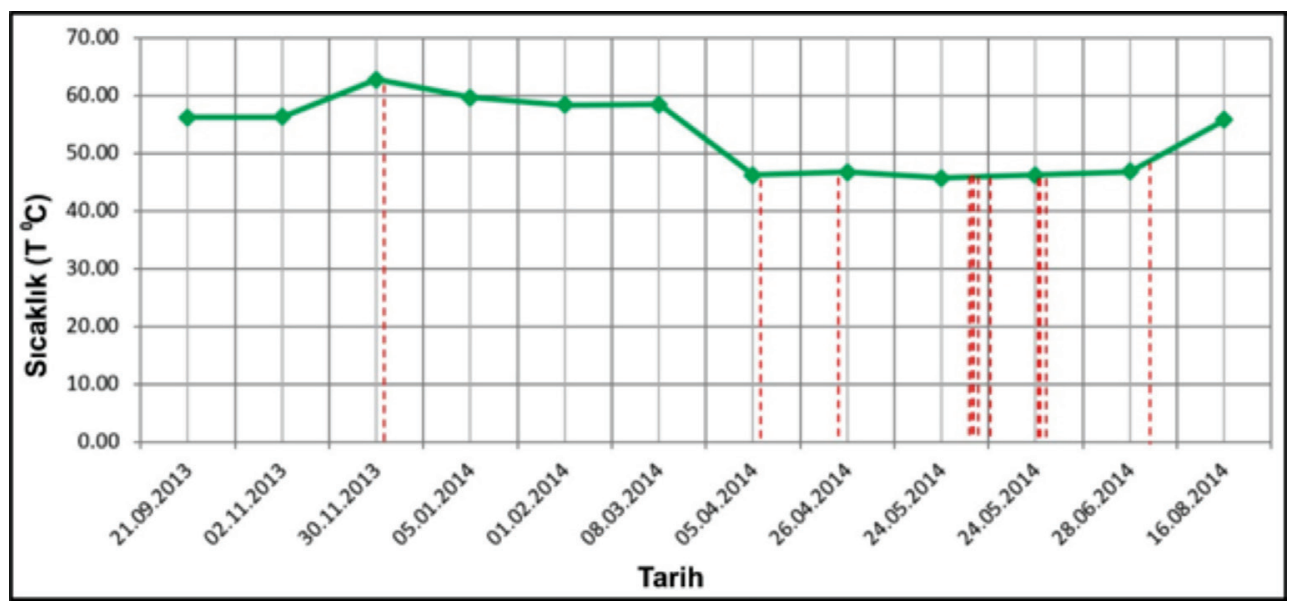

Şekil 9. Sıcaklık $\left(\mathrm{T}^{0} \mathrm{C}\right)$ değerlerindeki depremselliğe bağlı değişimler (kırmızı çizgiler depremleri göstermektedir) Figure 9. Temperature $\left(T^{0} \mathrm{C}\right)$ value changes connected with seismicity (red lines show earthquakes)

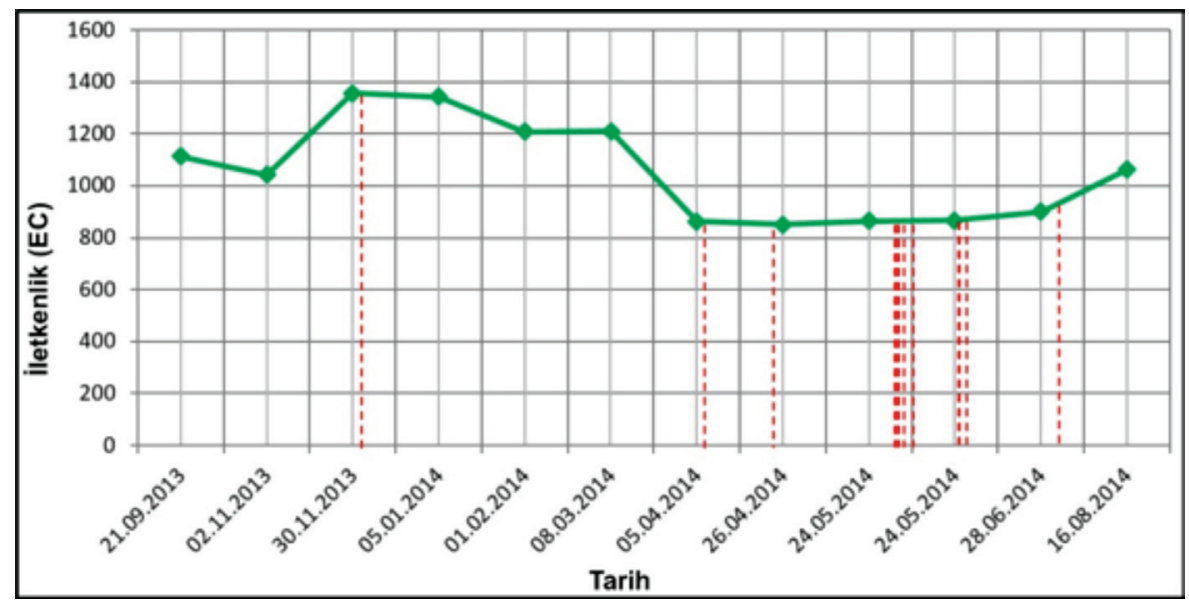

Şekil 10. İletkenlik (EC) değerlerindeki depremselliğe bağlı değişimler (kırmızı çizgiler depremleri göstermektedir)

Figure 10. Conductivity (EC) value changes connected with seismicity (red lines show earthquakes) 


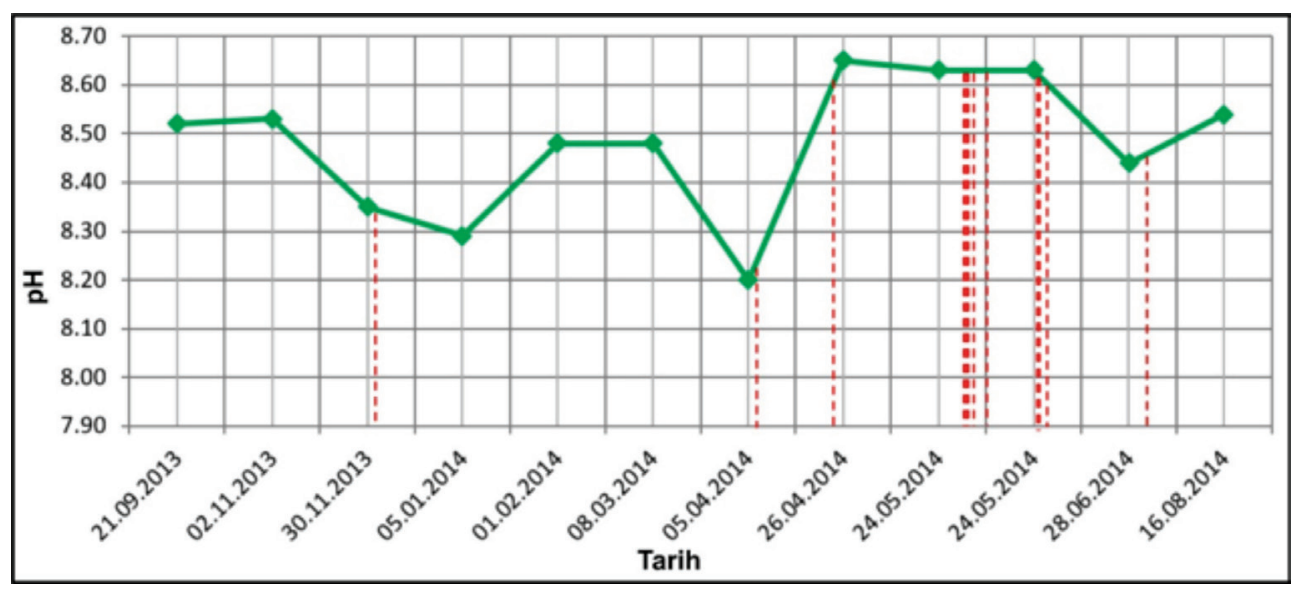

Şekil 11. pH değerlerindeki depremselliğe bağlı değişimler (kırmızı çizgiler depremleri göstermektedir)

Figure 11. $p H$ value changes connected with seismicity (red lines show earthquakes)

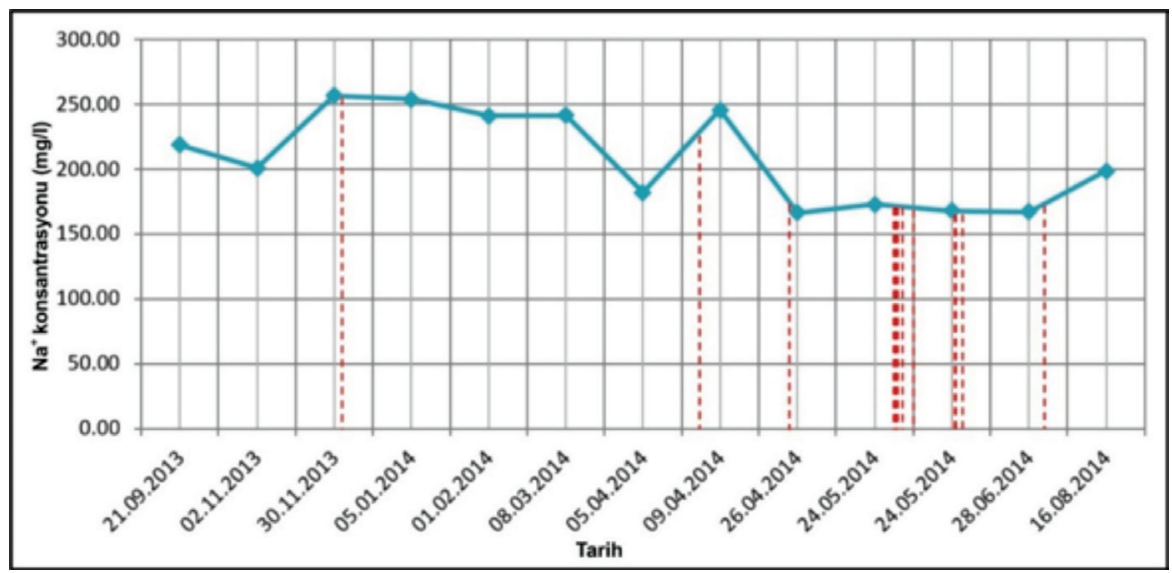

Şekil 12. $\mathrm{Na}^{+}$iyon değerlerindeki depremselliğe bağlı değişimler (kırmızı çizgiler depremleri göstermektedir)

Figure 12. $\mathrm{Na}^{+}$ion concentration changes connected with seismicity (red lines show earthquakes)

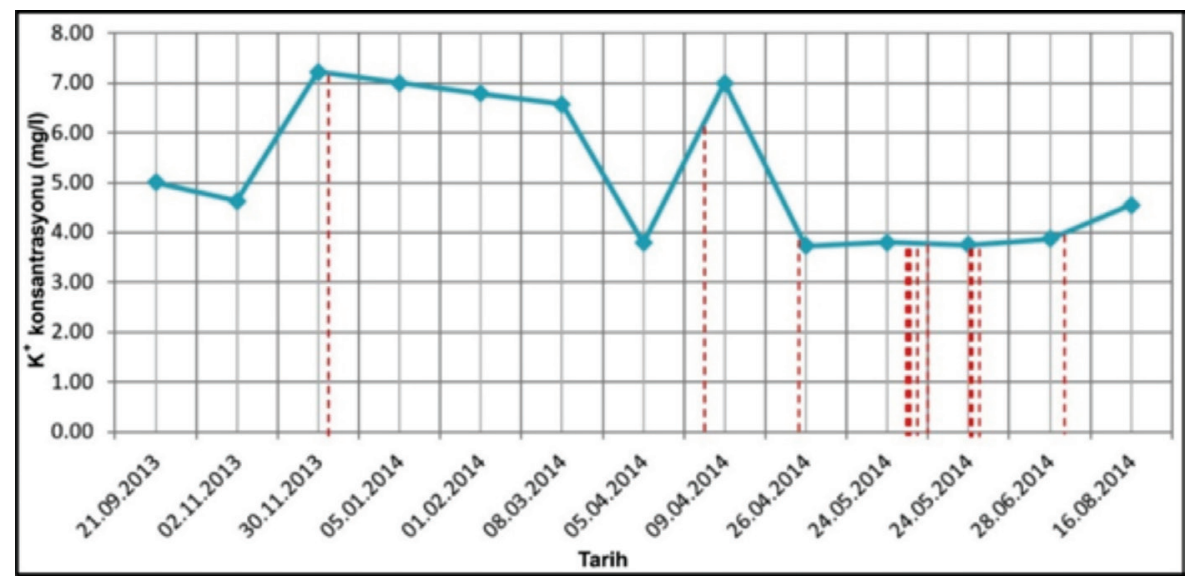

Şekil 13. $\mathrm{K}^{+}$iyon değerlerindeki depremselliğe bağlı değişimler (kırmızı çizgiler depremleri göstermektedir)

Figure 13. $K^{+}$ion concentration changes connected with seismicity (red lines show earthquakes) 


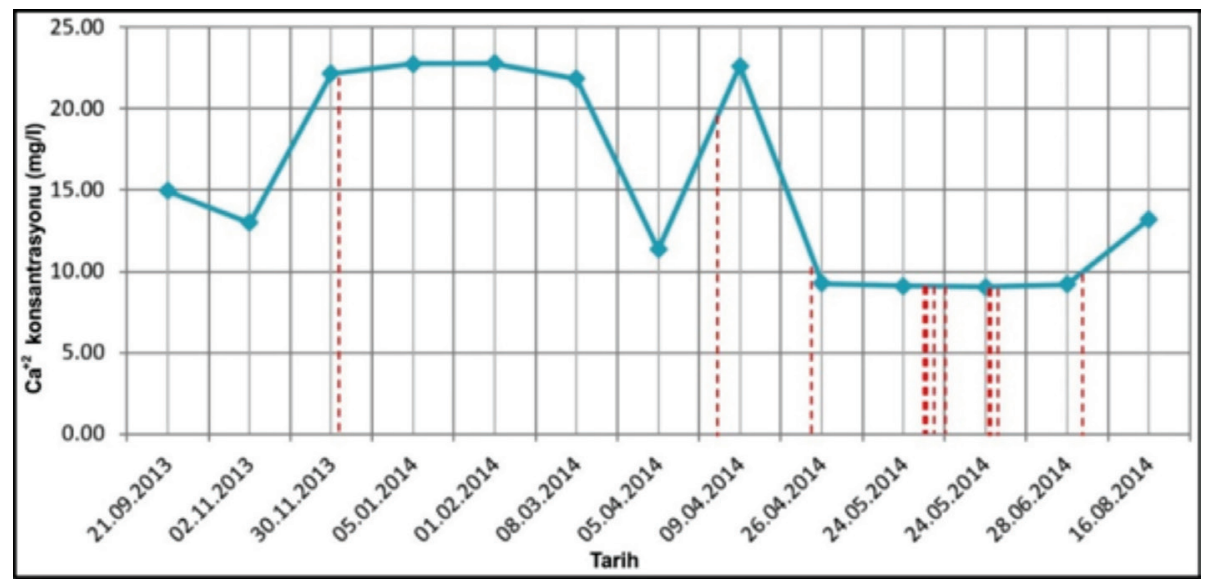

Şekil 14. $\quad \mathrm{Ca}^{+2}$ iyon değerlerindeki depremselliğe bağlı değişimler (kırmızı çizgiler depremleri göstermektedir) Figure 14. $\quad \mathrm{Ca}^{+2}$ ion concentration changes connected with seismicity (red lines show earthquakes)

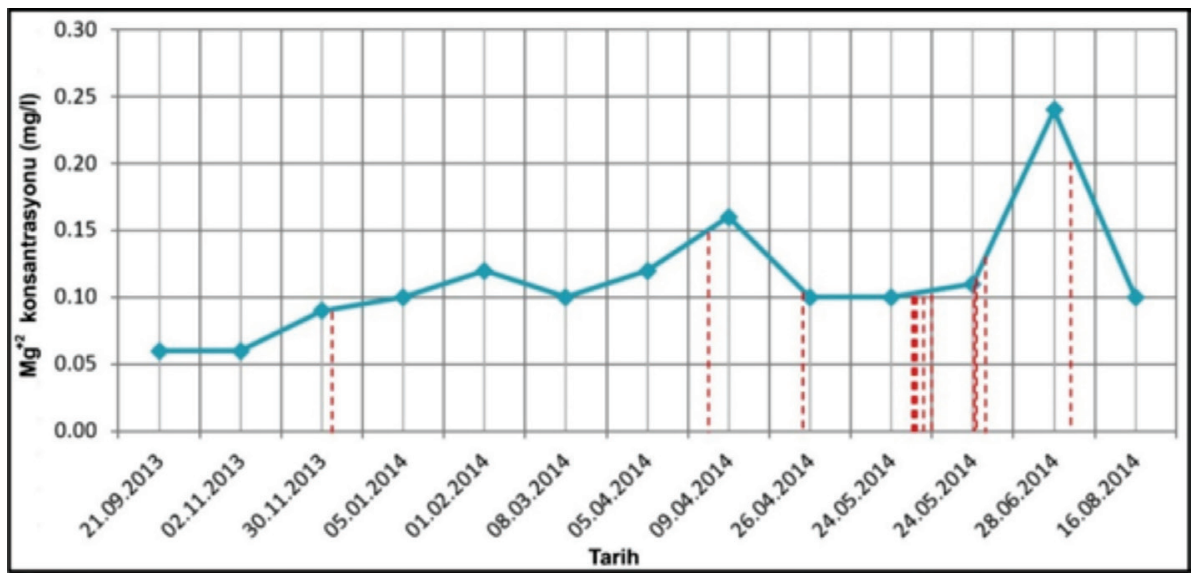

Şekil 15. $\mathrm{Mg}^{+2}$ iyon değerlerindeki depremselliğe bağlı değişimler (kırmızı çizgiler depremleri göstermektedir) Figure 15. $\mathrm{Mg}^{+}$ion concentration changes connected with seismicity (red lines show earthquakes)

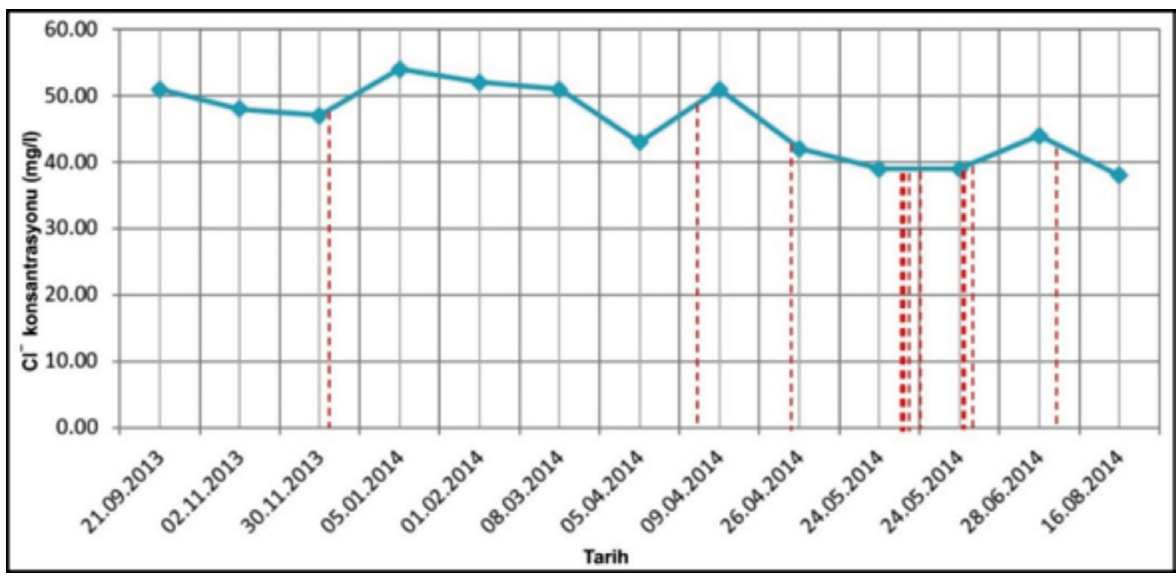

Şekil 16. $\mathrm{Cl}^{-}$iyon değerlerindeki depremselliğe bağlı değişimler (kırmızı çizgiler depremleri göstermektedir)

Figure 16. $\mathrm{Cl}$ ion concentration changes connected with seismicity (red lines show earthquakes) 


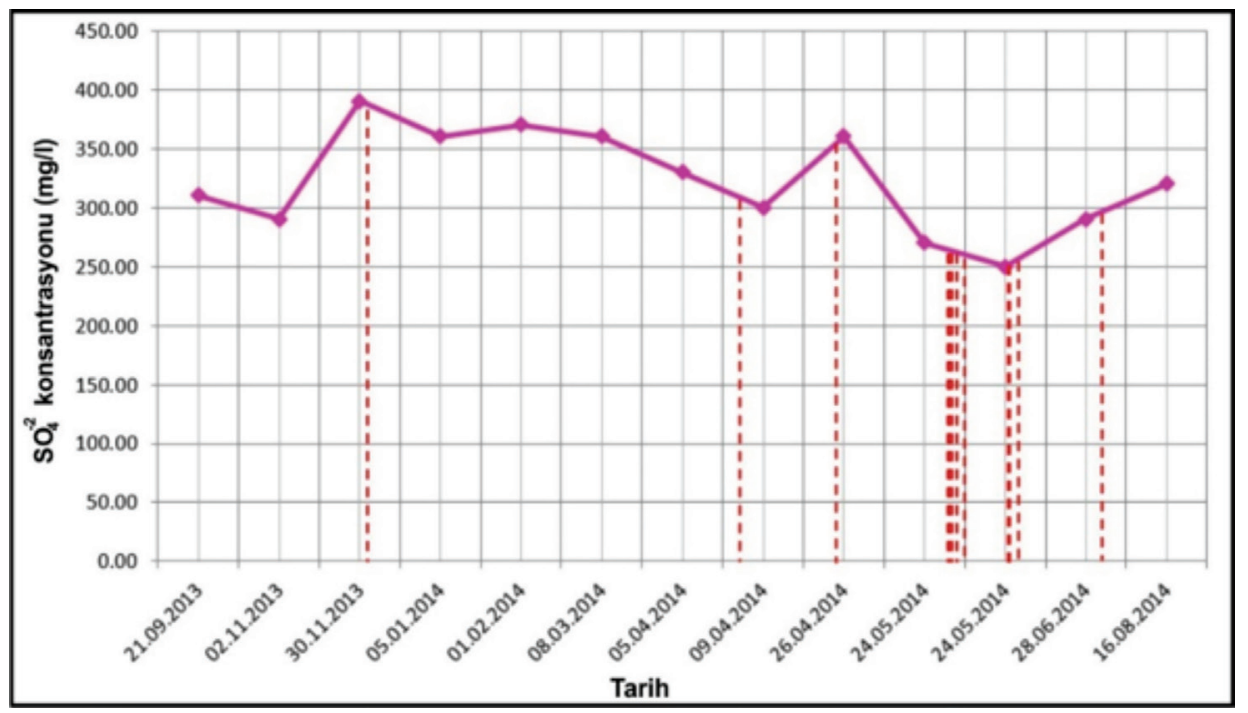

Şekil 17. $\mathrm{SO}_{4}^{-2}$ iyon değerlerindeki depremselliğe bağlı değişimler (kırmızı çizgiler depremleri göstermektedir) Figure 17. $\mathrm{SO}^{-2}$ ion concentration changes connected with seismicity (red lines show earthquakes)

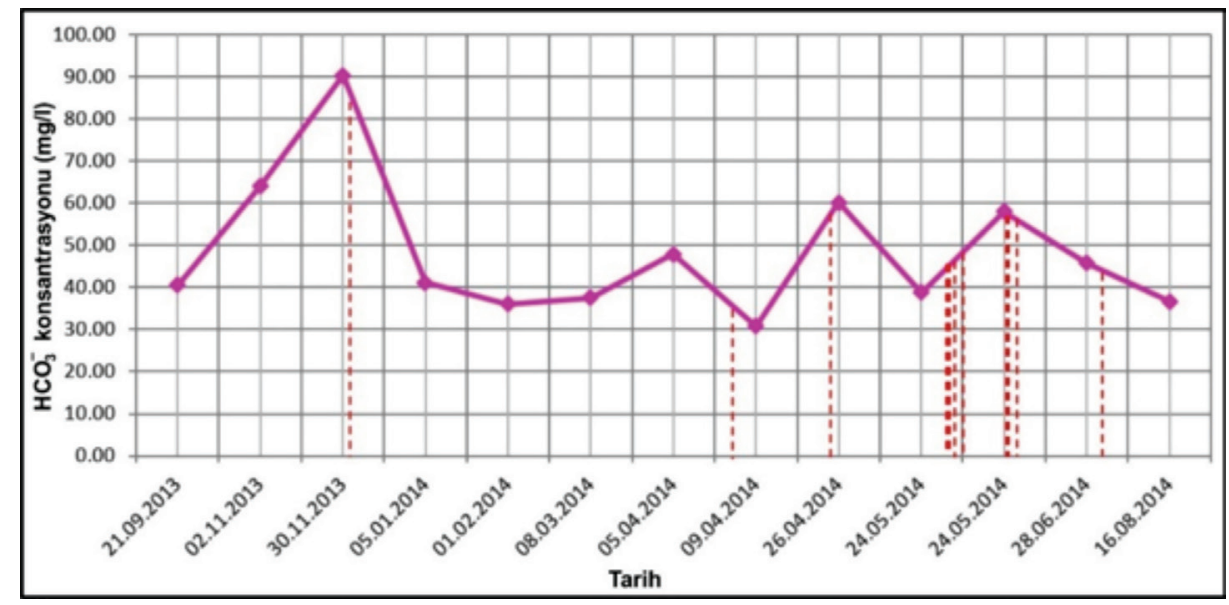

Şekil 18. $\mathrm{HCO}_{3}^{-}$iyon değerlerindeki depremselliğe bağlı değişimler (kırmızı çizgiler depremleri göstermektedir) Figure 18. $\mathrm{HCO}_{3}^{-}$ion concentration changes connected with seismicity (red lines show earthquakes)

\section{TARTIŞMA ve SONUÇLAR}

Çalışma alanında daha önce yapılmış jeoloji ve aktif fay haritaları da kullanılarak bölgenin jeoloji haritası yapılmıştır. Çalışma alanında dokuz farklı kaya birimi ayırtlanmıştır. Temelde Paleozoyik yaşlı Kazdağ Grubu'na ait metamorfik kayalar bulunmaktadır. Bunların üzerinde uyumsuzlukla Triyas yaşlı Karakaya Formasyonu yer almaktadır. Kretase yaşlı Çetmi melanjı,
Triyas yaşlı Karakaya Formasyonu üzerine tektonik dokanakla gelmektedir. Üst OligosenAlt Miyosen yaşlı Hallaçlar volkaniti ve OligoMiyosen granodiyoritleri alttaki tüm yaşl1 birimleri kesmektedir. Kuvaterner yaşlı alüvyon çalışma alanındaki tüm birimleri uyumsuz olarak üzerlemektedir. Ayrıca çalışma alanında başlıca KD-GB ve K-G yönlü sağ ve sol yönlü doğrultu atımlı faylar ve DKD-BGB doğrultulu eğim atımlı normal fayların geliştiği gözlemlenmiştir. 
Çalışma alanındaki jeotermal kaynak çıkışlarını sağlayan önemli tektonik hatların, basamak şeklinde sıralanan eğim atımlı normal faylar ve bu faylarla oluşmuş çatlak sistemleridir. Bölgede bulunan kaya birimleri derinlere süzülen sularının depolanabileceği gözenekli ve geçirimli ortam özelliğine sahiptirler. Kazdağ grubuna ait mermerler porozite ve permeabiliteye sahip hazne kaya özelliğindedir. Derinlerde 1sınan sular yine bu faylar ve çatlaklardan yeryüzüne ulaşmaktadır.

Çalışma alanı ve çevresinde aletsel dönemde meydana gelen 1912 Saros Körfezi-Mürefte (M:7.3, M:6.3), 1935 Erdek Körfezi (M:6.4), 1935 Çan-Biga (M:6.3), 1944 Edremit KörfeziAyvacık (M:6.8), 1953 Yenice-Gönen (M:7,2), 1964 Gönen (M:5,8), 1971 Edremit-Bakırçay (M:5,5), 1983 Biga (M:5,8), 2006 KuşgölüManyas (M:5,2) ve 2006 Bandirma (M:5.0) depremleri ve 2013 Kuzey Ege depremi (M:5.7) Biga Yarımadası, 24.05.2014 Gökçeada AçıklarıEge Denizi (M:6.5) depremleri bölgede belirgin bir sismik aktivitenin olduğunun göstergesidir.

$\mathrm{Bu}$ çalışma kapsamında Balıkesir ili, Edremit ilçesi, Güre beldesinde yer alan jeotermal alanda belirlenen sıcak su kaynağında Eylül 2013-Ağustos 2014 tarihleri arasında 12 örnekleme döneminde yerinde ölçüm ve su örneklemesi yapılmıştır. Çalışma alanında meydana gelen depremler ile termal sulardaki fiziksel ve/veya kimyasal değişimler korele edilmiştir. Buna göre alandaki depremlerle birlikte sicak sularda fiziksel ve kimyasal değişikler meydana geldiği görülmüştür.

Çalışma alanı ve yakın çevresinde Eylül 2013 tarihinden Ağustos 2014 tarihine kadar $\mathrm{M} \geq 3$ büyüklüğünde yaklaşı 12 adet deprem meydana gelmiştir. Güre jeotermal alanında 12 dönem (yaklaşık 1 ay ara ile) boyunca yapılan su fizikokimyası ölçüm ve deneysel çalışmalar sırasında eş zamanlı olarak bölgede olan depremler (24 Mayıs 2014 depremi ve artçılarıyla birlikte 12 adet deprem) öncesi ve sonrasında; bu termal sularda özellikle sıcaklık, pH ve elektriksel iletkenlik değerlerinde bir değişim olduğu gözlenmiştir. Bununla birlikte, bu suyun kimyasal analizleri sonucunda özellikle başta klorür $\left(\mathrm{Cl}^{-}\right)$, sodyum $\left(\mathrm{Na}^{+}\right)$ve sülfat $\left(\mathrm{SO}_{4}^{-2}\right)$ olmak üzere birçok elementel düzeyde artış ya da azalmanın olduğu tespit edilmiştir. Bu artış ve azalmanın (değişimin), bölgedeki aktif tektonik rejim ile doğrudan ilişkili olduğu sonucuna varılmıştır. Bununla birlikte, suyun fiziko-kimyasal değişimlerini iyi anlayabilmek için, depremlerin dişındaki diğer faktörleri (kuyu değişimi, mevsimsel etkiler, hazne kaya özellikleri, okuma-uygulama-ölçme hataları vb.) dikkatli bir şekilde ayırtlamak ve bundan sonra bu değişimleri yorumlamak gerekmektedir. Bu çalışma ile Güre jeotermal sisteminin hidrojeokimyasal bileşenlerinin sürekli ve uzun izlenmesi (monitoring) sayesinde bir depremin önceden tahmin edilebilmesi ile ilgili “tekrarlanabilir" önemli bilgiler elde edilebileceği sonucuna varılmıştır.

\section{KATKI BELIRTME}

Bu çalışma Çanakkale Onsekiz Mart Üniversitesi, Bilimsel Araştırma Projeleri Koordinasyon Birimi (ÇOMÜ-BAP) FYL-2014-188 nolu proje kapsamında gerçekleştirilmiştir.

\section{EXTENDED SUMMARY}

This study investigates the geology and hydrogeochemistry of Güre geothermal field and surroundings located in NW Anatolia in Ballkesir province, Edremit county, Güre town and deals with the correlation of these geothermal resources with active tectonism to research earthquake predictability.

The basic aim of this study is to measure in place, sample and analyze hot water resources from Güre geothermal field to determine parameters and their threshold values that may predict a possible earthquake in the region and close surroundings. Additionally, old and new 
earthquake data for Güre and close surroundings were examined.

The earthquakes occurring in the instrumental period in the study area and surroundings of 1912 Saros Bay-Mürefte (M:7.3, M:6.3), 1935 Erdek Bay (M:6.4), 1935 Çan-Biga (M:6.3), 1944 Edremit Bay-Ayvacı (M:6.8), 1953 YeniceGönen (M:7,2), 1964 Gönen (M:5,8), 1971 Edremit-Bakurçay (M:5,5), 1983 Biga (M:5,8), 2006 Kuşgölü-Manyas (M:5.2), 2006 Bandırma (M:5.0), 2013 Northern Aegean earthquake (M:5.7), Biga Peninsula, and 24.05.2014 offshore Gökçeada-Aegean Sea (M:6.5) indicate there is clear seismic activity in the region.

The basement of study area is rocks of the Paleozoic Kazdăg Group. The Triassic-age Karakaya Formation unconformably lies above the basement. The Cretaceous Çetmi melange tectonically overlies this basement. The Upper Oligocene-Lower Miocene Hallaçlar volcanics and Oligo-Miocene granodiorites were emplaced by cutting all older units. Quaternary alluvium unconformably overlies all units in the study area. Güre geothermal field is controlled by a ENEWSW oriented, south-dipping normal fault.

In the Güre geothermal heat center, water resources from four hot water wells called IGJ1, IGJ-2, IGJ-3 and IGJ-4 had measurements and water sampling performed in 12 sampling periods between September 2013 and August 2014. Earthquakes occurring in the study area were correlated with physical and/or chemical variations in thermal waters.

In the study area and surroundings, 12 earthquakes occurred with magnitude $M \geq 3$ between September 2013 and August 2014. During the 12 monitoring periods (at nearly 1 month intervals) physico-chemical measurements and experimental studies of water from Güre geothermal field were compared simultaneous to earthquakes in the region (12 earthquakes of 24 May 2014 earthquake and aftershocks). Before and after earthquakes changes were observed in these thermal waters, especially temperature, $\mathrm{pH}$ and electrical conductivity values. Additionally chemical analysis of the water identified increases or reductions in many elemental levels, especially $\mathrm{Cl}$, $\mathrm{Na}^{+}$and $\mathrm{SO}_{4}^{-2}$. It was concluded that these variations were directly related to the active tectonic regime in the region. To better understand the physico-chemical changes in water, it is necessary to carefully distinguish other factors apart from earthquakes (well variations, seasonal effects, reservoir rock properties, readingapplication-measurement errors, etc.) and then interpret these variations.

In Güre geothermal field and close surroundings, it was concluded that the observation of variations (decrease-increase) in the physiochemistry of water before and after earthquakes occurring during the study period suggests that continuous monitoring of geothermal fields may be instructive for prediction of earthquakes.

\section{DEĞİNILEN BELGELER}

Akkuş, İ., Akıllı, H., Ceyhan, S., Dilemre, A. ve Tekin, Z., 2005. Türkiye Jeotermal Kaynakları Envanteri, MTA Genel Müdürlüğü Envanter Serisi-201, 849 s.

Alpar, B. and Yaltırak, C., 2002. Characteristic features of the North Anatolian Fault in the eastern Marmara region and its tectonic evolution, Marine Geology, Vol. 190, No. 1-2, s. 329-350, ISSN: 0025-3227, Elsevier B.V.

Ateş, Ö. ve Tutkun, S.Z., 2014. Simav (Kütahya) Depremlerinin Jeotermal Sistemlerdeki Hidrojeokimyasal Değişimleri, Türkiye jeoloji Bülteni, Cilt 57, Sayı 32, 25-40.

Ateş, 2014. Kütahya ve Simay Fayları Arasında Kalalan Jeotermal Alanların Hidrojeokimyası ve Aktif Tektonik İle İlişkisi, Çanakkale Onsekiz Mart Üniversitesi, Fen Bilimleri Enstitüsü, Doktora Tezi, $81 \mathrm{~s}$.

Bingöl E., 1968. Contribution a L' e' tude ge'ologiue de la Partir Centrale et sud-est du Massif de Kazdağ (Turquei). PhD Dissertation (Doktora Tezi). Nancy Univ. Fransa. 
Bingöl, E., 1975. 1:2 $500 \quad 000$ ölçekli Türkiye metamorfizma haritası ve bazı metamorfik kuşakların jeotektonik evrimi üzerinde tartışmalar. M.T.A. Derg., no. 83, Ankara.

Bingöl E., Akyürek B., Korkmazer B., 1973. Biga Yarımadasının Jeolojisi ve Karakaya Formasyonun Bazı Özellikleri. Cumhuriyetin 50. Y11 Yerbilimleri Kongresi, Ankara, 70-76.

Duru, M.,Ilgar, A., Dönmez M., Atabey, E., Pehlivan, Ş., Akçay, A.E., Şentürk, Y., Sezen Demirci, E., Ilgar, Y., Demirci, Ö., Bilgin, R., Eyüpoğlu, M., Kar, H., Özata, A., Sakitaş, A., Okay, A., Genç, Ş.C., Altunkaynak, Ş., 2007. Türkiye Jeoloji Haritaları İ17 Paftası, 1:100000, M.T.A, Ankara.

Ercan, T., Satır, M., Steinitz, G., Dora, A., Sarıfakıoglu, E., Adis, C., Walter, H.-J., Yıldırım, T., 1995. Biga Yarımadası ile Gökçeada, Bozcaada ve Tavsan adalarındaki (KB Anadolu) Tersiyer volkanızmasının ozellikleri. MTA Dergisi 117, 55-86 (in Turkish).

Eroğlu, A. ve Aksoy, N., 2003. Jeotermal Suların Kimyasal Analizi, VI. Ulusal Tesisat Kongresi, Jeotermal Enerji Semineri Kitapçı̆̆ı, 149-183.
Nicholson, K.,1993, Geothermal fluids: chemistry and exploration techniques, Springer-Verlag Berlin Heidelberg New York.

Okay, A.İ., 1987. The oxygen fugacity stability of deerite: an alternative view. Journal of Metamorphic Geology, 5, 553-555.

Okay A.İ., Siyako M., Bürkan K.A., 1990. Biga Yarımadasının Jeolojisi ve Tektonik Evrimi. TPJD Bült., 2/1: 83-121.

Şimşek, Ş., 2003, Hydrogeological and isotopic survey of geothermal fields in the Büyük Menderes Graben, Geothermics, 23, 669-478

Şimşek, Ş. ve Yıldırım, N., 2000. Termal Kaynaklar: Depremin habercisi, 17 Ağustos ve 12 Kasım 1999 deprem bölgelerindeki termal kaynaklarda gözlenen değişimler ve önemi, Cumhuriyet, Bilim Teknik, 01 Temmuz 2000.

Yüzer E. ve Tunay G., 2012. Biga Yarımadası'nın Genel ve Ekonomik Jeolojisi. Maden Tetkik ve Arama Genel Müdürlüğü, 28: 19-59.

http://udim.koeri.boun.edu.tr/ (Boğaziçi Üniversitesi, Kandilli Rasathanesi ve Deprem Araştırma Enstitüsü, Ulusal Deprem İzleme Merkezi) 